\title{
The Role of Ca Equilibrium on the Functional Properties of Cheese: A Review
}

\author{
Mee-Ryung Lee and Won-Jae Lee* \\ Division of Applied and Life Science (Institute of Agriculture and Life Science), \\ Gyeongsang National University, Jinju 660-701, Korea
}

\begin{abstract}
The functional properties of cheese, such as texture and melt, are known to be controlled by several important parameters. Recently, the characteristics of $\mathrm{Ca}$ in cheeses, especially the form of $\mathrm{Ca}$ (insoluble (INSOL) or soluble) and the shift in Ca equilibrium (i.e., from INSOL to soluble $\mathrm{Ca}$ ), during aging has received a lot of attention. The INSOL form of $\mathrm{Ca}$, which is present as a structural form in casein, plays a critical role in determining the functional properties of cheese during the early period of ripening ( 1 mon). It seems that there is always a reduction of INSOL Ca content in cheese during ripening and there are also factors that can affect the shift in Ca equilibrium. These factors may include the composition of cheese milk, cheese manufacturing $\mathrm{pH}$, acid development during aging, adopting curd-washing in various methods, pre-acidification of milk, etc. There have been many studies showing that the rheological and melting properties of cheese during ripening were significantly $(p<0.05)$ affected by the shift in Ca equilibrium. Therefore, for cheese makers, it is now possible to predict/ manage the functional properties of cheese by monitoring and controlling Ca equilibrium in cheese during aging.
\end{abstract}

Key words: Ca equilibrium, insoluble $\mathrm{Ca}$, cheese functionality

\section{Introduction}

Cheese is now widely used in all over the worlds due to its versatile adaptability as a food ingredient. To prepare each food, different functional properties of cheese are required to obtain specific attributes of each food. For example, to get a smooth and creamy texture of tiramisu, mascarpone cheese is normally used while fresh Mozzarella cheese is commonly used for caprese salads to give a curdy texture. Therefore, understanding the functional properties of cheese, such as texture and melting behavior when heated, becomes a great importance to manipulate the proper functionality of each cheese. To accomplish this purpose, there have been tremendous studies to understand the physico-chemical properties of cheese from the manufacture to its end-use (e.g., Lucey et al., 2003).

During last decades, there was a remarkable progress in understanding the role of $\mathrm{Ca}$ in the functional properties of cheeses (Hassan et al., 2004; Johnson and Lucey,

\footnotetext{
*Corresponding author : Won-Jae Lee, Division of Applied and Life Science (Institute of Agriculture and Life Science), Gyeongsang National University, Jinju 660-701, Korea. Tel: 82-55-751-5412, Fax: 82-55-751-5410, E-mail: wjleewisc@ gnu.ac.kr
}

2006; Lucey and Fox, 1993; Lucey et al., 2005). Until early 90es, it was perceived among cheese makers that most of $\mathrm{Ca}$ in cheese milk is dissolved from casein-structure during manufacture and that major controlling factors in the functional properties of cheeses during ripening is proteolytic activity either by enzyme or bacteria (Lawrence et al., 1987). Nowadays, it is believed by many cheese researchers and cheese makers that $\mathrm{Ca}$ in cheese also can determine the physico-chemical and functional properties of cheese as a reasonable amount of Ca turned out to be present inside of casein after cheese making. In this review, some key perspectives of Ca equilibrium in cheese and its role on the functional properties of cheeses will be discussed.

\section{Ca in Milk and Cheese}

The total $\mathrm{Ca}$ concentration in milk is $\sim 26-32 \mathrm{mM}$, which is approximately $117 \mathrm{mg} / 100 \mathrm{~g}$ of milk (Schmidt, 1980; Walstra, 1990). The concentration of $\mathrm{Ca}$ and other minerals in milk can vary according to the stage of lactation, nutritional status of the cows and environmental and genetic factors (Roginski et al., 2003). Mean concentrations of the major minerals in cows' milk are shown in Table 1. It is estimated that around $32 \%$ of total $\mathrm{Ca}$ is present in serum phase as soluble complexes $(10 \mathrm{mM})$ 
Table 1. Mean concentrations of the main macrominerals in cows' milk (Walstra et al., 1999)

\begin{tabular}{lc}
\hline \hline Minerals & Content $(\mathrm{mg} / 100 \mathrm{~g}$ of milk) \\
\hline Sodium & 53 \\
Potassium & 136 \\
Chloride & 97 \\
Calcium & 112 \\
Phosphorus & 89 \\
Magnesium & 11 \\
\hline
\end{tabular}

and free ions $(3 \mathrm{mM})$. The remainders of $\mathrm{Ca}$ is associated with casein micelles (i.e., exists as structural form) and called colloidal calcium phosphate (CCP) or insoluble (INSOL) Ca. The total calcium content of cheese varieties varies mostly due to differences in the manufacturing $\mathrm{pH}$ values, especially $\mathrm{pH}$ at whey draining (Lee et al., 2005; Lucey and Fox, 1993; Yun et al., 1995). Table 2 shows $\mathrm{Ca}$ content in various cheeses. The high calcium content of Emmental cheese is obtained by having high ( 6.0) draining $\mathrm{pH}$ while low calcium content of cottage cheese is mainly due to low ( $\sim 5.2)$ draining $\mathrm{pH}$.

\section{Colloidal Calcium Phosphate (CCP)}

$\mathrm{CCP}$ is also known as nanocluster and the exact structural form of CCP is still controversial. It is believed that the molar ratio of $\mathrm{Ca}$ bound to inorganic phosphate $(\mathrm{Ca} /$ P) is 1.5-1.6 (Pyne and McGann, 1960; Walstra and Jenness, 1984). It has been reported that $\mathrm{CCP}$ in milk has form of $3 \mathrm{Ca}_{3}\left(\mathrm{PO}_{4}\right)^{\bullet} \mathrm{CaH}$ citrate; $\mathrm{Ca}_{9}\left(\mathrm{PO}_{4}\right)_{6} ; \mathrm{CaHPO} \bullet 2 \mathrm{H}_{2} \mathrm{O}$, which is acidic, amorphous, and reminiscent of brushite (Holt et al., 2003; Schmidt, 1980). The total amount of CCP is about $7 \mathrm{~g} / 100 \mathrm{~g}$ dry casein (Walstra et al., 1999). CCP is one of the minor constituents of the casein micelles (Fox and McSweeney, 1998) but CCP is one of the principal structural elements (Horne, 1998). CCP acts as a neutralizing or cross linking agent in casein micelles, i.e., it helps in maintaining the integrity of casein micelles. CCP is being positively charged (Schmidt, 1980) and binds to negatively charged phosphoserine clusters. This

Table 2. Calcium content in various cheese (Kosikowski and Mistry, 1997)

\begin{tabular}{lc}
\hline \hline Cheese variety & Content $(\mathrm{mg} / 100 \mathrm{~g}$ of milk $)$ \\
\hline Cottage & 80 \\
Camembert & 400 \\
Cheshire & 550 \\
Edam & 750 \\
Cheddar & 800 \\
Gouda & 820 \\
Emmental & 920 \\
\hline
\end{tabular}

leads to reduce the charges of protein to the level to make the attractive interactions dominated between hydrophobic regions of casein (Horne, 1998). Dissolving CCP by decreasing milk $\mathrm{pH}$ (completed by $\mathrm{pH} \sim 5.0$ ) disrupts the stability of casein micelles (Dalgleish and Law, 1989; Lucey et al., 1997; Pyne and McGann, 1960).

\section{The form of $\mathrm{Ca}$ in cheese and changes in $\mathrm{Ca}$ equi- librium during cheese ripening}

Cheese making is a dehydration process of milk in which casein and fat are concentrated about 10 folds (for Cheddar cheese) (Lucey et al., 2003). During cheese making, most of serum $\mathrm{Ca}$ is lost during draining and casein-bound $\mathrm{Ca}$ is dissolved when the draining $\mathrm{pH}$ is lowered (Lucey and Fox, 1993). Until recently, it was believed that the CCP in milk was completely solubilized during manufacture of cheese and that $\mathrm{Ca}$ in cheese was only present in serum phase as most of INSOL Ca in milk is dissolved with $\mathrm{pH}<5.2$ (Choi et al., 2007; Pyne and McGann, 1960). The early attempts to quantify soluble $\mathrm{Ca}$ (that fraction that is in serum phase) and INSOL Ca (that fraction that is attached to casein) in cheeses were performed by Lucey and Fox (1993) and Morris et al. (1988). Both studies suggested that there were a large amount of INSOL Ca still remained after cheese making. Morris et al. (1988) reported that $\sim 56 \%$ of total $\mathrm{Ca}$ in cheese was present as colloidal forms in 1 mon Cheddar cheese in the form of $\mathrm{Ca}$ associated with para-casein or in the form of Ca phosphate crystals. Lucey and Fox (1993) reported that both cheese $\mathrm{pH}$ and the amount of $\mathrm{CCP}$ remained after cheese manufacture had important effects on the cheese texture. Lucey and Fox (1993) also reported that the buffering capacity of cheese was primarily determined by the amount of CCP remained after cheese manufacture. Therefore, cheese manufacturing conditions, such as the rate of acid development and draining $\mathrm{pH}$, are important in determining the buffering capacity of cheese since the concentration of CCP is altered by these manufacturing conditions. However, changes in this INSOL Ca during cheese ripening and their effects on the functional properties of cheese were not investigated extensively until recently.

Hassan et al. (2004) developed two robust methods to quantify the INSOL and soluble Ca content in Cheddar cheese during ripening. It is now possible to monitor the proportion of INSOL and soluble $\mathrm{Ca}$ as a percent of the total $\mathrm{Ca}$ content of cheese during ripening using either of these two methods. One approach is called cheese juice method (Hassan et al., 2004; Lee et al., 2005; Lee, 2007; 
Lucey and Fox, 1993; Monib, 1962; Morris et al., 1988). In cheese juice method the serum phase of cheese is extracted by hydraulic pressure and this extracted juice was used for $\mathrm{Ca}$ measurement. Another method is the acid-base titration method, which measures the buffering capacity contributed by residual CCP using acid-base titration and this buffering capacity is used to quantify the amount of $\mathrm{Ca}$ associated with casein micelles (Hassan et al., 2004; Lucey et al., 2005; O'Mahony et al., 2005). By using these two methods it has been demonstrated that there are significant changes/reduction in INSOL Ca content of Cheddar cheese during ripening and that the proportion of INSOL $\mathrm{Ca}$ in Cheddar cheeses decreased from $\sim 70$ to $56 \%$ during the first 3 mon of ripening (Hassan et al., 2004; Lucey et al., 2005). It was also observed that most of the decrease in the INSOL Ca content of cheese occurred during the first month and after this period no large changes were observed (Hassan et al., 2004; Lee et al., 2005; Lee, 2007; Lucey et al., 2005) (Fig. 1).

The impact of some manufacturing variables, i.e., different $\mathrm{pH}$ values during manufacture, altered lactose content of cheese milk, washing and different ways of curd washing was also investigated. Cheddar cheese with low manufacturing (renneting and draining) $\mathrm{pH}$ and with two different lactose contents (4.5 and 5\%) in cheese milk was made to find out the changes in Ca equilibrium during ripening. The reduction of INSOL Ca content of cheese was accelerated with elevated lactic acid level (due to low manufacturing $\mathrm{pH}$ ) during ripening (Lee et al., 2005). Surprisingly, there was a still significant amount of INSOL Ca content of cheese (more than $40 \%$ as a $\%$ of total Ca content of cheese) remained after 3 mo ripening even in cheeses with pH 4.7 (Lee et al., 2005). This indicates the attainment of "pseudo-equilibrium" in cheese during ripening.

O'Mahony et al. (2006) reported that precipitation occurred when the concentration of $\mathrm{Ca}$ in a synthetic

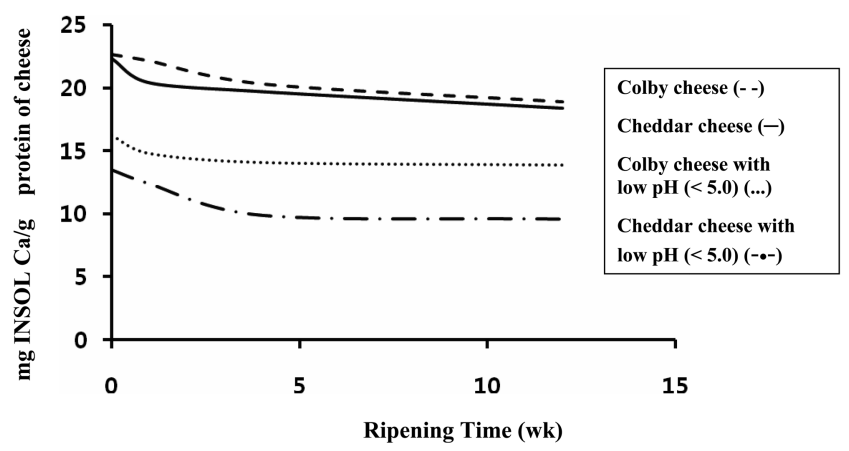

Fig. 1. Changes in INSOL Ca content of various cheeses during ripening (approximation only).
Cheddar cheese aqueous phase solution exceeded $900 \mathrm{mg}$ $/ 100 \mathrm{~g}$ (they made this solution targeting 4 mon old cheese juice). It has been suggested that establishment of a pseudo-equilibrium between INSOL and soluble forms of $\mathrm{Ca}$ in the cheese matrix is a driving force contributing to the solubilization of $\mathrm{CCP}$ in cheese during ripening (Hassan et al., 2004; Lucey et al., 2005; O’Mahony et al., 2006). The observed increase in solubility of $\mathrm{Ca}$ and precipitation of $\mathrm{Ca}$ in cheese juice may reflect this attainment of a new stable pseudo-equilibrium between soluble and INSOL Ca in cheese (Hassan et al., 2004; Lee et al., 2005; O'Mahony et al., 2006). It is also possible that there are other limiting factors that influence the solubility of $\mathrm{Ca}$ phosphate in cheese, such as $\mathrm{pH}$, interactions with other ions, and high ionic strength.

Lee (2007) investigated the changes in INSOL Ca content of Colby (washed curd) cheese during ripening; there was also a significant reduction of INSOL Ca content of cheese during the first mon of ripening. With curd-washing, it was possible to prevent extreme drop of cheese $\mathrm{pH}$ during ripening especially for the cheese with elevated lactose content of cheese milk or with low manufacturing pH. Changes in INSOL Ca content of Colby cheese were also significantly $(p<0.05)$ affected by the different ways of curd-washing, such as batch and continuous washing (Lee, 2007). It was also observed that there was a reduction of INSOL Ca content of cheese during ripening even if there was an increase in cheese $\mathrm{pH}$, which indicates that a decrease in cheese $\mathrm{pH}$ is not necessary to have a shift of INSOL to soluble form of Ca (Lee, 2007).

\section{The Role of $\mathrm{Ca}$ in cheese on textural and melting properties of cheese}

During ripening texture of cheese generally changes from curdy (short) to smooth and soft structure (Lawrence et al., 1987). Also more flow and higher meltability of cheese during heating are commonly observed with aging (Lucey et al., 2005). For a long time it was believed that the proteolysis (either by enzymatic or by bacterial activity) occurred during ripening is the major contributing factor in textural changes of cheese during ripening (Lawrence et al., 1987). It was also generally recognized that lower total $\mathrm{Ca}$ content of cheese gives softer and more meltable cheeses (Lucey and Fox, 1993). But recently, it seemed that the textural changes of cheese during early period of ripening ( 1 mon) are more correlated with the reduction of INSOL $\mathrm{Ca}$ content than with proteolysis (Lucey et al., 2005; O'Mahony et al., 2006). Also there were differences in melting behavior of cheese even with 
similar total $\mathrm{Ca}$ content of cheese indicating that total $\mathrm{Ca}$ is not a precise predictor of textural and melting properties of cheese during aging (Lee, 2007).

The rheological properties of Cheddar cheese during heating (represented by storage modulus and maximum loss tangent) were more highly correlated with the INSOL $\mathrm{Ca}$ content of cheese than with the level of 4.6-soluble nitrogen which represent the extend of primary proteolysis during 9 mon aging (Lucey et al., 2005). There was a significant $(p<0.05)$ reduction in hardness of Cheddar cheese in large deformation test (Texture Profile Analyzer) during first $21 \mathrm{~d}$ of ripening when hydrolysis of $\mathrm{a}_{\mathrm{s1}}$-casein at $\mathrm{Phe}_{23}-\mathrm{Phe}_{24}$ was completely blocked or inhibited at all stage of ripening $(180 \mathrm{~d})$ by the addition of pepstatin (a potent inhibitor of chymosin) with a concentration of 10 $\mu \mathrm{mol} / \mathrm{L}$ of cheese milk during cheese making (O'Mahony et al., 2005).

It seems that lower INSOL Ca content of cheese gives more meltable and softer cheese (Choi et al., 2007; Hassan et al., 2004; Lee, 2007; Lucey and Fox, 1993; Lucey et al., 2005; O'Mahony et al., 2005 and 2006) (Fig. 2). O'Mahony et al. (2006) varied the concentration of INSOL Ca in cheese from 1.36 to $2.36 \mathrm{~g} \mathrm{Ca} / 100 \mathrm{~g}$ of protein in cheese by incubating 4 mon old Cheddar cheese slices in synthetic Cheddar cheese aqueous phase solutions containing various levels of $\mathrm{Ca}$. With a significant increase in INSOL Ca content of cheese the $\mathrm{LT}_{\max }$ value (meltability index) decreased significantly $(p<0.05)$ from 0.7 to 1.7 and the force to compress the cheese by 5 , 20 and $75 \%$ of its original height increased significantly $(p<0.05)$ in large deformation test (O'Mahony et al., 2005).

Choi et al. (2007) reported that INSOL Ca content of cheese was varied either pre-acidification of cheese milk with lactic acid or chelating $\mathrm{Ca}$ in cheese milk with ethylenediamine tetraacetic acid (EDTA). The INSOL Ca con-

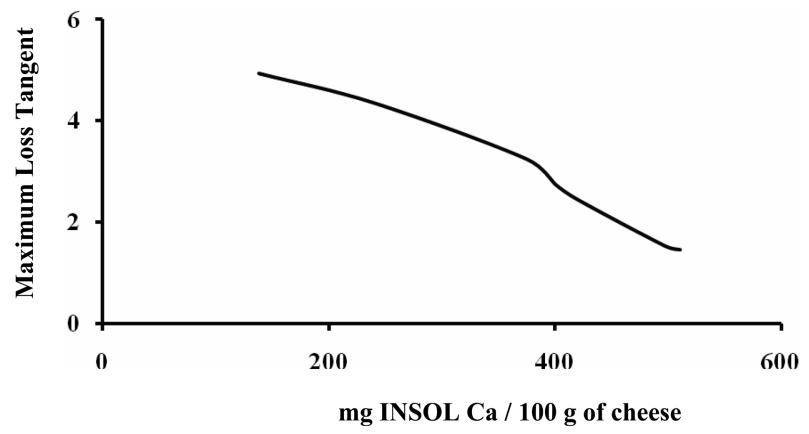

Fig. 2. Maximum loss tangent value (meltability index) during heating with various amount of INSOL Ca content of cheese (approximation only). tent of cheese was varied from 337 to $823 \mathrm{mg} / 100 \mathrm{~g}$ of cheese with pre-acidification of cheese milk and from 375 to $511 \mathrm{mg} / 100 \mathrm{~g}$ of cheese with the addition of EDTA to cheese milk, respectively. As INSOL Ca content of cheese decreased in both EDTA and pre-acidification treatment, the $\mathrm{LT}_{\max }$ value (melatability index) was increased from 1.52 to 4.93 and 1.45 to 3.24 , respectively. This result indicates that cheese has more flexible (less cross-linking) casein network with less amount of INSOL Ca.

In Lee (2007), the total Ca content of 4 types of Colby cheese from different curd-washing method was not significantly $(p<0.05)$ different $(\sim 700 \mathrm{mg} / 100 \mathrm{~g}$ of cheese) . For the first $2 \mathrm{wk}$, the INSOL Ca content of cheese, however, was varied from 18 to $23 \mathrm{mg}$ INSOL Ca per g protein in cheese resulting in significantly $(p<0.05)$ higher $\mathrm{LT}_{\max }$ value for the cheese with lower INSOL Ca content (ranging from 0.82 to 2.13). This result shows that the amount of INSOL $\mathrm{Ca}$ in cheese can be the determining factors in melting behavior of cheese when total $\mathrm{Ca}$ content, $\mathrm{pH}$, cheese moisture, and the level of 4.6 soluble nitrogen of cheese are not significantly $(p<0.05)$ different (Lee, 2007).

\section{Conclusion}

The scientific and precise ways to monitor the quantity of INSOL Ca content of cheese, such as cheese juice and titration methods during aging were developed during last two decades. It seems that the solubility of INSOL Ca in milk and in cheese is different due to the differences in the amount of serum phase present. It was found that INSOL Ca content of cheese is a crucial factor to affect cheese functionality (such as texture and melting) during early period of ripening. It was also found that shift in $\mathrm{Ca}$ equilibrium in cheese i.e., shift from INSOL to soluble form of $\mathrm{Ca}$, can be controlled or affected by the cheese manufacturing variables, such as lactose content of cheese milk, acid development during cheese making, curdwashing and curd-washing methods as well as the level of lactic acid at post manufacture. It is now possible for cheese-makers and cheese researchers to check the INSOL $\mathrm{Ca}$ content of cheese using newly developed method and use that information as one of the key parameters to predict the functional properties of cheeses.

\section{Acknowledgements}

This study was supported by Technology Development 
Program for Agriculture and Forestry, Ministry for Food, Agriculture, Forestry and Fisheries, Republic of Korea (Project: 107072-3).

\section{References}

1. Choi, J., Horne, D. S., and Lucey, J. A. (2007) Effect of insoluble calcium concentration on rennet coagulation properties of milk. J. Dairy Sci. 90, 2612-2623.

2. Dalgleish, D. G. and Law, A. J. R. (1989) pH induced dissociation of bovine casein micelles. II. Mineral solubilization and its relation to casein release. J. Dairy Res. 56, 727-735.

3. Fox, P. F. and McSweeney, P. L. H. (1998) Chemistry and biochemistry of cheese and fermented milk. In: Dairy Chemistry and Biochemistry. Blackie Academic \& Professional, London, pp. 419-421.

4. Hassan, A., Johnson, M. E., and Lucey, J. A. (2004) Changes in the proportions of soluble and insoluble calcium during the ripening of Cheddar cheese. J. Dairy Sci. 87, 854-862.

5. Holt, C., de Kruif, C. G., Tuinier, R., and Timmins, P. A. (2003) Substructure of bovine casein micelles by small angle X-ray and neutron scattering. Colloid Surface A. 213, 275284.

6. Horne, D. S. (1998) Casein interactions: Casting light on the black boxes, the structure in dairy Products. Int. Dairy J. 8, 171-177.

7. Johnson, M. E. and Lucey, J. A. (2006) Calcium: A key factor in controlling cheese functionality. Aust. J. Dairy Technol. 61, 147-153.

8. Kosikowski, F. V. and Mistry, V. V. (1997) Cheese and fermented milk foods. 3rd ed, L. L. C., Westport, CN, Vol 1, pp. 204-226.

9. Lawrence, R. C., Creamer, L. K., and Gilles, J. (1987) Texture development during cheese ripening. J. Dairy Sci. 70, 1748-1760.

10. Lee, M. -R. (2007) Understanding Ca equilibrium in cheese during ripening and its effects on functional properties of cheese. Ph. D. thesis, University of Wisconsin-Madison, USA.

11. Lee, M. -R., Johnson, M. E., and Lucey, J. A. (2005) Impact of modifications in acid development on the insoluble $\mathrm{Ca}$ content and rheological properties of Cheddar cheese. $J$. Dairy Sci. 88, 3798-3809.

12. Lucey, J. A. and Fox, P. F. (1993) Importance of calcium and phosphate in cheese manufacture: A review. J. Dairy Sci. 76, $1714-1724$

13. Lucey, J. A., Dick, C., Singh, H., and Munro, P. A. (1997)
Dissociation of colloidal calcium-phosphate depleted casein particles as influenced by $\mathrm{pH}$ and concentration of calcium and phosphate. Milchwissenschaft 52, 603-606.

14. Lucey, J. A., Johnson, M. E., and Horne, D. S. (2003) Perspectives on the basis of the rheology and texture properties of cheese. J. Dairy Sci. 86, 2725-2743.

15. Lucey, J. A., Mishra, R., Hassan, A., and Johnson, M. E. (2005) Rheological and calcium equilibrium changes during ripening of Cheddar cheese. Int. Dairy J. 15, 645-653.

16. Monib, A. M. M. F. (1962) The calcium-paracaseinatephosphate complex under conditions similar to those in cheese. Meded. Land-bouwhogesch Wageningen. 62, 1-76.

17. Morris, H. A., Holt, C., Brooker, B. E., Banks, J. M., and Manson, W. (1988) Inorganic constituents of cheese: Analysis of juice from a one-month-old Cheddar cheese and the use of light and electron microscopy to characterize the crystalline phases. J. Dairy Res. 55, 255-268.

18. O’Mahony, J. A., Lucey, J. A., and McSweeney, P. L. H. (2005) Chymosin-mediated proteolysis, calcium solubilization, and texture development during the ripening of Cheddar Cheese. J. Dairy Sci. 88, 3101-3114.

19. O’Mahony, J. A., McSweeney, P. L. H., and Lucey, J. A. (2006) A model system for studying the effects of colloidal calcium phosphate concentration on the rheological properties of Cheddar cheese. J. Dairy Sci. 89, 892-904.

20. Pyne, G. T. and McGann, T. C. A. (1960) The colloidal calcium phosphate of milk. 2. Influence of citrate. J. Dairy Res. 27, 9-17.

21. Roginski, H., Fuquay, J., and Fox, P. F. (2003) Encyclopedia of dairy science. Academic press, San Diego, CA, Vol. 1, pp. 252-444.

22. Schmidt, D. G. (1980) Colloidal aspects of casein. Neth. Milk Dairy J. 34, 42-64.

23. Walstra, P. (1990) On the stability of casein micelles. $J$. Dairy Sci. 73, 1965-1979.

24. Walstra, P. and Jenness, R. (1984) Dairy Chemistry and Physics. John Wiley and Sons, New York.

25. Walstra, P., Geurts ,T. J., Noomen, A., Jellema, A., and van Boekel, M. A. J. S. (1999) Dairy technology: Principles of Milk Properties and Processes. Marcel Dekker, Inc., New York.

26. Yun, J. J., Barbano, D. M., Kindstedt, P. S., and Larose, K. L. (1995) Mozzarella cheese: impact of whey $\mathrm{pH}$ at draining on chemical, composition, proteolysis, and functional properties. J. Dairy Sci. 78, 1-7.

(Received 2009.9.7/Accepted 2009.10.12) 